\title{
Roman Wine in Barbaricum. Preliminary Studies on Ancient Wine Recreation
}

\author{
Iwona Feier ${ }^{1, *}$, Aleksandra Migała ${ }^{1}$, Marta Pietruszka ${ }^{1}$ and Mateusz Jackowski ${ }^{2}$ \\ 1 Faculty of Historical and Pedagogical Sciences, Institute of Archaeology, University of Wroclaw, Szewska 48, \\ 50-139 Wrocław, Poland; aleksandra.migala@uwr.edu.pl (A.M.); marta.pietruszka2@uwr.edu.pl (M.P.) \\ 2 Division of Bioprocess and Biomedical Engineering, Faculty of Chemistry, Wroclaw University of Science \\ and Technology, Norwida 4/6, 50-373 Wrocław, Poland; mateusz.jackowski@pwr.edu.pl \\ * Correspondence: iwona.feier@uwr.edu.pl
}

Received: 31 December 2018; Accepted: 22 January 2019; Published: 24 January 2019

check for updates

\begin{abstract}
Ancient Roman wine is found outside of the borders of the Roman world as a result of the Roman influence, trade and political relations. In our project, we decided to extensively research and recreate the ancient method of wine making in order to understand ancient viticulture and viniculture as it could have been if implemented outside of the borders. The objective was to recreate roman wine using ancient methods based on ancient texts (such as Columella, Pliny the Elder, Cicero, Cato the Elder, Galenus and Mago). The wine was made using modern grapes grown on lands considered by the Romans as barbaric (i.e., outside the Roman Limes), in modern Poland. The aim of the project-except for the wine making itself — was to measure the level of alcohol created through fermentation process. Ethanol levels in samples were obtained using gas chromatography (GC).
\end{abstract}

Keywords: wine; ancient Rome; viticulture; viniculture; alcohol analysis

\section{Introduction}

Grapes are among the oldest fruits in the world. Several dozens of species belonging to the Vitaceae family have been discovered and meticulously described. According to the most recent research, modern grapevines (Vitis vinifera sativa) originated from a wild grape of the Vitis vinifera subsp. sylvestris [1]. Wild grapevines used to occur in the Eurasian region which spread westwards from Central Asia to the Iberian Peninsula and southwards from the Crimea to Northern Africa in the warm periods of the Pleistocene and Holocene [2]. It is believed that domestication of wild grapes was due to the crossing of wild and domesticated strains [3]. Vitis vinifera has been used mainly for the production of wine and this alcoholic drink was an important part of the ancient Meditearranean diet. Grapes, along with olives and grain, formed what we know now as the 'Meditearranean Triad' — three most nutritious and vital foods [4].

It is common knowledge that food products deposited in prehistoric times are not preserved in their original, nor even similar form. Archeologists and researchers of related sciences (such as archaeobotany, palynology or archaeozoology) derive information about the diet from found plant (pollen, grains, fruit stones) and animal remains (bones above all) as well as from bone isotope studies. Food residues accumulate also in the form of lipids and deposits on the inner walls of the vessels in which they were prepared or stored [5]. The same problem occurs when it comes to wine. Currently, the earliest trace of wine production is considered to have been found on a ceramic vessel, on which the residues of tartaric acid were identified. The vessel, dated to the end of the 6th millennium BC, was discovered in the Iranian site Hajji Firuz Tepe, north of the Zagros Mountains. It is possible that the ceramic container was filled with wine made from wild grapes [6]. Only one (and the oldest in Europe) finding of wine in liquid form (Figure 1) comes from the area of our interest, which is European 
Barbaricum in the first centuries of the current era. It was found in Speyer, a town located on the Rhine in the state Rhineland-Palatinate in Germany. This wine, dating back to $325 \mathrm{AD}$, is preserved in a greenish-yellow, cylindrically shaped glass bottle with two dolphin-shaped handles and was retrieved from a tomb of a man and a woman of Roman origin [7].

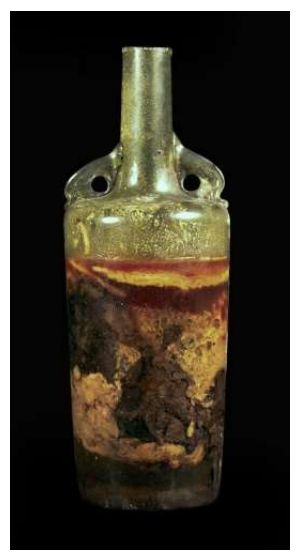

Figure 1. Speyer wine. Source: https:/ / www.speyer.de, accessed on 19 December 2018.

However, how do we know that the Barbarians, fond of drinking beer and mead, also imbibed wine? This is already mentioned by Publius Cornelius Tacitus-a Roman historian who wrote down (around $98 \mathrm{AD}$ ) the history of Germanic tribes outside the Roman borders in De origine et situ Germanorum, widely known as the Germania. In chapter XXIII Tacitus wrote:

'For their drink, they draw a liquor from barley or other grain; and ferment the same so as to make it resemble wine. Nay, they who dwell upon the bank of the Rhine deal in wine' (Germania, XXIII) [8].

We should note that this passage mentions only the tribes near the Rhine; however, it does not mean that the Germans who lived farther from the Limes did not know the taste of wine.

We know from other written sources that the Romans conquering the areas farther up north used to set up their own vineyards, therefore making wine transport from the southern parts of the Empire unnecessary. Vineyards were also established in Germania Superior which allowed growing vines, despite rather unfavorable conditions, unlike in Italy [9]. Hence, the barbarian tribes living at the Roman border and the Germans inhabiting the Roman provinces could have seen how to manage grapevines.

An important note is incorporated in the Corpus Iuris Civilis. It records the Emperor Flavius Iulius Valens' prohibition of exporting wine, oil and other liquids outside of the territory of the Roman Empire issued at the end of the 4th century [10]. It shows us the possibility of a cross-border wine trade between the Romans and Barbarians, which means that at least some of the Germanic tribes could have imbibed wine.

Moreover, certain types of items from grave inventories of the Barbarians point to the consumption of wine in the Barbaricum. The context of such discoveries clearly indicates that it was a drink that only high-ranked members of society could afford [11]. It is noteworthy that wine could have been a kind of gift from the Romans to members of the Barbarian elite connected with the commanders or other important people from the Roman Empire. Sets of bronze dishes (such as jars, scoops and strainers) along with glass horns (often with bronze fittings) and silver cups for drinking, usually placed in the so-called princely graves confirm the wine consumption and indicate the area of its occurrence outside of the Empire. What is more, similar vessels occur in rich graves, located from the Rhine in the south to Scandinavia in the north (Figure 2). Sets of identical vessels imported from Rome to Barbaricum were used in the Empire for mixing with water, seasoning, straining, and drinking wine. Such vessels were also put into rich burials, but their function was not certain and has been widely discussed by modern scholars. It is assumed that they might have served various roles, e.g., a symbol 
of buried person's social status or wealth. Many of them are visibly only imitating originals and have been crafted in unspecified workshops in Barbaricum. Some of them bear no traces of use, whereas others (especially sets of jugs and bowls) were used for different purposes both in Barbaricum and in Rome [11-13]. Their presence might not be related to wine-lack of confirmatory evidence suggests it is necessary to perform appropriate vessel analyses to trace any particles indicating types of drinks poured into them. Such investigation was conducted on a bronze situla from the Havor hoard found on Gotland dated to the first century AD [14].

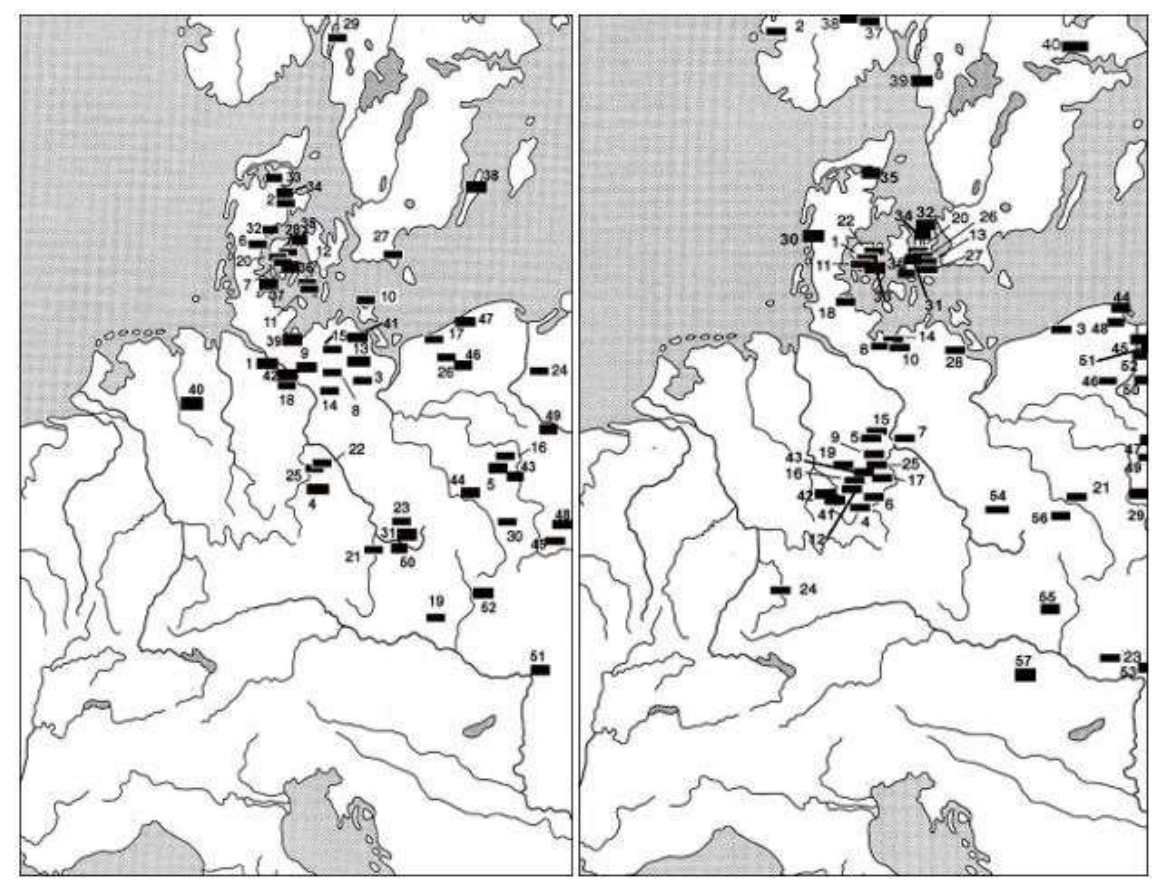

Figure 2. Maps showing range of occurrence of vessels for preparing and drinking wine on the example of princely graves. The first map shows burials from Lubieszewo phase (periods B1-B2 of Roman period), and the second-burials from Haßleben-Leuna-Zakrzów phase (periods B2/C1-C2). Source: M. Gebühr 1998, pp. 186-187 with additions made by A. Migała [15].

Communities living in the area of contemporary Poland during the Roman period could have been making fruit wine from the fruits available to them. The fermentation process was certainly known to them, since they produced beer and mead [16]. The abovementioned analysis of the situla from Havor, yielded evidence that the vessel presumably originally contained a drink prepared from berries and from vegetable juice, e.g., from birch juice [14] which indicates even higher plausibility that Germans made some sort of wine from local fruits.

\subsection{Archaeology of Roman wine}

Archaeobotany explores plant residues from archaeological sites. Due to archaeobotanical research, we know which plants were used in human life in the past. Interpretation of botanical analyses depends on the context of the presence of remains, their number, state of preservation (carbonised, charred, uncharred etc.) and from which part of the plant they come from (seeds, shells, grains etc.). For instance, in ancient botanical material charred seeds can come from plants that were used for consumption. In addition to macrofossils, researchers examine microfossils namely pollen, phytoliths and silica skeletons from plants remaining after the death of the organism. Microfossils allow determining which plants used to grow near excavated sites. The remains or traces on the walls of the vessels are currently being investigated using molecular biology methods, e.g., DNA analyses [4]. 
Archaeobotanical research from archaeological excavation indicates that grapes were first domesticated by humans in the Near East in the Chalcolithic and Early Bronze Age. Although there are some hypotheses regarding an earlier domestication of Vitis vinifera sylvestris in the Stone Age, earliest convincing archaeological data supported by evidence of carbon dated charred grape pips from Levantine sites set the domestication time and the beginning of the earliest known viniculture between 9th and 6th millennium BC [3]. The oldest remains of wild vines were discovered in Nevali Çori in Turkey and date to 8400 BC. In continental Europe, the oldest remains were discovered in Greece and date to the Early Stone Age. Botanical remains discovered in France (south Languedoc) come from the Middle Stone Age whereas remains discovered in the Apennine Peninsula come from the Late Stone Age [3]. As for the cradle of winemaking - or the discovery of the power of a fermented grape juice-scholars tend to point to regions where uncultivated grapes would naturally occur in abundance allowing them to naturally ferment and produce an early wine-like product that attracted humans. Such conditions existed south of the Caucasus and in the Caspian regions, namely in current Armenia (and possibly Georgia) [17].

At the beginning, people used a wild form of Vitis for their needs: mainly to produce moderate amount of wine or as fresh fruits. Archaeobotanical research proves that both wild and cultivated species have been grown. Despite extensive interdisciplinary research projects, the dawn of viticulture is not entirely clear. The tillage of vines began in the 4th millenium BC and spread beyond areas of wild grapes around the middle of the 3rd millenium BC. In Europe, however, the proof of wild grape domestication was found in Greece and Crete, where such cultivation dates back to around 2000 BC [3].

\subsection{Roman Viticulture and Viniculture}

The roman Empire played an important role in distribution of grapes and wine. The oldest botanical remains on the Apennine Peninsula are dated to the second half of the 1st millennium BC. The Romans learned about wine and viticulture from the Greeks, Etruscans, and also from Egyptians and Carthaginians as well as Phoenicians. From the kingdom period through the Early Republic there is little to no evidence providing support for the hypothesis of the Romans being an active winemaking state from the very beginning. On the contrary, Roman viticulture seems to have originated from just a branch of horticulture, gradually becoming one of the most important foundations of Republican and Imperial agriculture and thus economy. Being focused merely on the conquest of neighbor states, tribes, and further in subordination of the whole Apennine Peninsula, Romans relied mainly on Greek wine with their own viticulture (as well as viniculture) not being a matter of their primary interest [18]. Only having conquered the Peninsula, Rome grew significantly from a city-state to a local hegemon to the most powerful state in the Mediterranean. Along and through such political and military surge, its economy thrived. In the 2nd century BC, when most of Rome's vital powers were focused on growth and expansion, wine was already one of the foundations of the economy. The 2nd century BC marks a milestone in the history of Roman wine and viticulture: as of this time, the viticulture was supporting the development of viniculture which began with the Romans being fond of wine made by the Greeks or Etruscans, then gradually learning from them, and eventually surpassing them by building a wine industry that left an imprint everywhere the Romans went.

Through expansion of the Roman Empire, grapes reached the farthest Roman provinces and then expanded beyond the Limes [3]. An example of such a province was Pannonia (contemporary west Hungary, east Austria, north Croatia, Slovenia and north-west Serbia [19]). Plants like plums, peaches and grapes were brought along with Roman settlers. The abundance of plants favored by the Romans suggests intense horticulture and viticulture which played an important role in this region. In $92 \mathrm{AD}$, emperor Domitian issued an edict ordering destruction of vineyards beyond Italy. It was supposed to curb diseases destroying grape bushes. As strict as it was, it did not end Roman viticulture in provinces. After the fall of the Roman Empire grapes and other fruits were still farmed. In Europe, along with the expansion of Christianity, wine drinking culture spread again $[3,20]$. 
In Europe, north of the Limes, archaeological remains of cultivated grapes come from e.g., Slovakia [21] and Germany [22]. In Poland, remains of grapes dating back to Roman Period (or earlier) have not been found yet. The oldest traces of wild or domesticated grapes come from the Early Middle Ages from Cracow [21]. It may be due to the fact that the people living in today's Poland either may have not produced wine and their knowledge regarding wine was a result of trade relations, or remains of Vitis did not survive in archaeological sites. Perhaps further research will verify this hypothesis.

\section{Materials and Methods}

\subsection{Roman Wine Literature}

Roman viticulture grew from a Carthaginian treaty written by Mago and copied per Senate's request after the second Punic war. Interestingly, the same Marcus Porcius Cato the Elder who reportedly insisted on the destruction of Carthage, was also the one who wrote an agricultural treatise including passages on winemaking, especially numerous recipes regarding wine and changes to its quality, taste or clarity [23]. Roman agriculturers and winemakers drew from Mago's work that sets the foundation for what we know today as typical Roman viticulture. Current knowledge on ancient Roman viticulture and viniculture is based on archaeological, epigraphical, and archaeobotanical data along with ancient literary sources. Cato's treatise has often been transmitted along with a newer work on agriculture by Marcus Terentius Varro: De Re Rustica-a technical treatise intended as practical manual on farming for his wife. Book one contained precise instructions regarding planting, cultivation, harvesting, storage, and use of grapes as well as crops and olives [24]. Although the agricultural manual written by Mago in Punic has now been lost for centuries, parts of its Latin translation provided by Decimus Iunius Silanus [25] are still known today. Lucius Iunius Moderatus Columella in his agricultural handbook De Re Rustica drew from the body of knowledge offered by the works of his predecessors, and enhanced it by adding his knowledge based on the newest techniques used in then Roman agriculture, horticulture, and husbandry [26-28]. He occasionally made references to Cato and Varro, his own work being used the same way later by Gaius Plinius Secundus i.e., Pliny the Elder. Pliny's Naturalis Historia is the latest of the most valuable agricultural treatises and manuals containing chapters and books on wine itself, grape farming, winemaking, and viniculture [25]. It is a monumental work about nature and natural world, and one of the largest single works surviving from Roman times, bearing some characteristics of an encyclopedia and later becoming an example of such work. Although pieces of Roman literature on agriculture have been preserved in much greater variety than abovementioned works, those four treatises form the most important body of sources on ancient Roman wine, viticulture, and viniculture [29].

\subsection{The Experiment}

The aim of the project was reconstruction of the wine making process in the Roman period. Following the recipes and manuals regarding wine and the improvement of its quality or taste included in ancient texts mentioned in Section 2.1, it was decided to produce condimented wine. Grapes used to make the wine were bought in a local shop. After the separation of petioles from the fruit, $7 \mathrm{~kg}$ of preprocessed fruit was obtained. Then, gently rinsed grapes were put into a stoneware vessel, which quality resembles properties of the vessels used for winemaking in the Roman period. Afterwards, fruits were crushed and the juice from the first pressing was obtained. It was the most desired and expensive juice used to produce the highest quality wine. Finally $3 \mathrm{~L}$ of liquid was produced from $7 \mathrm{~kg}$ of fruit after removing pits and skins from the juice. The liquid was left for fermentation at a constant temperature of $20{ }^{\circ} \mathrm{C}$. The opening of the tank was covered with natural fabric to allow release of carbon dioxide and to protect fermenting liquid from any dust, dirt, pollution, and insects. Spontaneous fermentation began after 5 days. It was indicated by the appearance of white foam on the surface of the liquid. Once in a while, the juice was mixed with oak branches. After 9 days, counting from the beginning of fermentation, spices such as: black pepper $(5 \mathrm{~g})$, cinnamon $(10 \mathrm{~g})$, cardamom 
(5 g), and multiflorous honey (700 g) were added and mixed with the liquid using an oak branch. After another 4 days, the liquid was filtered through a natural linen textile. During the organoleptic validation performed by 10 volunteers, the taste was generally described to be very sweet and spicy, much like a lighter version of mulled wine. The liquid was not clear, however it did not affect its taste. The wine diluted with tap water had a more pleasant taste than the original, undiluted tasting sample.

After tasting, the wine was divided into two parts and poured into glass bottles. Both bottles were then left for one month in order to observe any changes in preservation at different storing conditions. Sample 1 was stored at room temperature $\left(20\right.$ to $\left.22^{\circ} \mathrm{C}\right)$ whereas Sample 2 was stored in a refrigerator at a constant temperature of $6{ }^{\circ} \mathrm{C}$ (Figure 3).

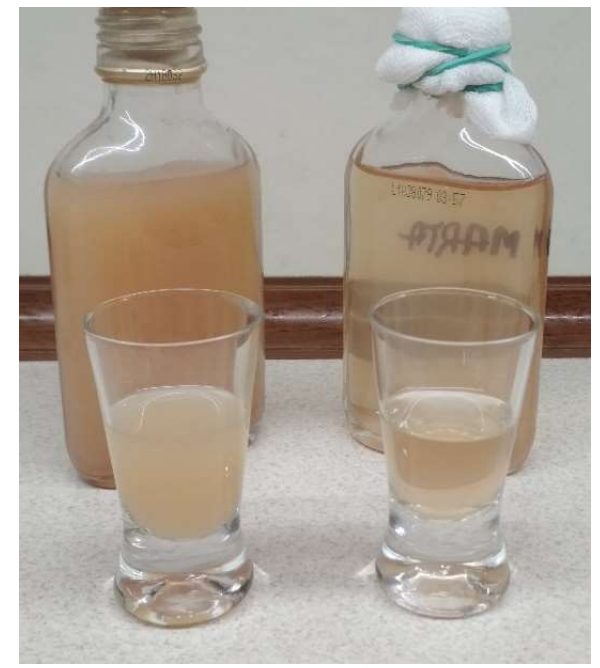

Figure 3. Wine samples before analysis. Left: Sample 2 (stored at $6{ }^{\circ} \mathrm{C}$ ); right: Sample 1 (stored at room temperature).

There are plenty of volatile compounds present in wine. Some of them are responsible for its taste and aroma [30]. The most interesting among them is ethanol. This compound has a strong influence on the taste of a product and it significantly affects human behavior. The simplest way to check alcohol content in standard wine is to measure its relative density using a hydrometer. Unfortunately, it is hard to identify all of the volatile compounds present in produced wines. Moreover, their influence on the density of analyzed samples is unknown. To eliminate such aberrations, a gas chromatograph (GC) was used for the measurement. In this device, samples are vaporized and separated on a stationary phase located in the chromatographic column. Separation is possible due to difference in molecular weight of compounds (bigger molecules migrate slower through the column). The first step of the analysis was to prepare reference samples with known alcohol content. Using reference solutions, standard curve was achieved along with correlation between alcohol content and peak integration. Finally, using knowledge of retention time of ethanol and the standard curve obtained in the previous step of the analysis, it was possible to measure the alcohol content in the wine. The results were as follows: $13.1 \%$ of alcohol by volume in Sample 1 and $11.8 \%$ of alcohol by volume in Sample 2 .

\section{Results}

Produced wine was turbid but represented proper organoleptic characteristics. The taste was very intense, sweet, and spicy, so it was necessary to dilute the wine before consumption. Gas chromatography yielded the following results regarding alcohol content in analyzed samples: $11.8 \%$ alcohol by volume in Sample 2 (stored at $6{ }^{\circ} \mathrm{C}$ ) and $13.1 \%$ alcohol by volume in Sample 1 (stored at room temperature of $20-22{ }^{\circ} \mathrm{C}$ ). The alcohol content is similar to that of wines commercially available in Poland. Such results suggest that honey added as a flavor delivered additional sugar for fermentation. Wine stored at room temperature (Sample 1) had a higher alcohol content due to storage conditions 
optimal for yeast activity, whereas lower storing temperature for Sample 2 turned out suboptimal for fermentation, effectively slowing down the process which resulted in lower alcohol content. Another interesting observation is that wine stored at a lower temperature was more turbid than the sample stored at room temperature.

Those preliminary results are simply a harbinger of a more complex further study. The ongoing project will include advanced analyses of different types of ancient Roman wine currently being produced from various types of grapes.

\section{Conclusions}

Our experiment proves it possible to produce wine using the ancient Roman method and contemporary grapes grown on former barbaric lands. Strong, sweet, and spicy taste differs from the taste of wines known to today's customers and wine fiends. Different taste might have also been caused by the presence of wild strains of yeast prevalent in ancient wines-contrary to pure cultures used currently in the wine industry. Honey added to the wine delivered sugars that were fermented by yeast, remained after standard fermentation, and therefore allowed for a higher alcohol level and more complex aroma. This issue, however, requires more thorough further investigation.

Considering the number of findings suggesting ancient wine presence far beyond the Roman Limes, e.g., various types of vessels that were used to drink, sift, and dilute wine found in princely graves from the Roman Period, there is still a lot to discover regarding its presence and role on barbaric land. Numerous archaeobotanical remains of fruit stones as well as traces of fermented products reveal more information about the Barbarians and their viniculture when put under thorough investigation using modern analytical techniques. Again, it is worth mentioning that lack of plant remains should not discourage researchers from further investigations.

Author Contributions: Conceptualization, I.F., A.M., M.P.; methodology, I.F., A.M.; investigation, M.J.; resources, M.P.; data curation, M.J.; writing—original draft preparation, I.F., A.M., M.P., M.J.; writing-review and editing, I.F., M.J.; visualization, A.M.; supervision, I.F.; project administration, M.P.

Funding: This research received no external funding.

Conflicts of Interest: The authors declare no conflict of interest.

\section{References}

1. Terral, J.-F.; Tabard, E.; Bouby, L.; Ivorra, S.; Pastor, T.F.; Igueiral, I.; Picq, S.; Chevance, J.B.; Jung, C.; Fabre, L.; et al. Evolution and history of grapevine (Vitis vinifera) under domestication: New morphometric perspectives to understand seed domestication syndrome and reveal origins of ancient European cultivars. Ann. Bot. 2010, 105, 443-455. [CrossRef] [PubMed]

2. McGovern, P. The Origins and Ancient History of Wine; Gordon and Breach Publishers: Amsterdam, The Netherlands, 2005; p. 26.

3. Góralczyk, A. Vitis vinifera sylvestris i vitis vinifera sativa. Udomowienie i upowszechnienie się uprawy winorośli w starym świecie na podstawie badań archeologicznych i paleobotanicznych. Folia Praehist. Posnan. 2016, XXI, 123-148.

4. Day, J. Botany meets archaeology: People and plants in the past. J. Exp. Bot. 2013, 64, 5805-5816. [CrossRef] [PubMed]

5. Lucquin, A.; Colonese, A.C.; Farrell, T.F.G.; Craig, O.E. Utilising phytanic acid diastereomers for the characterization of archaeological lipid residues in pottery samples. Tetrahedron Lett. 2016, 57, $703-707$. [CrossRef]

6. Bouby, L.; Marinval, P. La vigne et les débuts de la viticulture en France: Apports de l'archéobotanique. Gallia 2001, 58, 13-28. [CrossRef]

7. Speyer. Available online: https://www.speyer.de (accessed on 19 December 2018).

8. Tacitus. Tacitus on Germany; Gordon, T., Trans.; New York, 1910. Available online: http:/ /www.gutenberg. org/files/2995/2995-h/2995-h.htm (accessed on 14 December 2018).

9. Hornsey, I. The Chemistry and Biology of Winemaking, 1st ed.; RSC Publishing: Cambridge, UK, 2007. 
10. Justinian. Corpus Iuris Civilis; Scott, S.P., Trans.; Cincinnati, 1932. Available online: https:/ /droitromain.univgrenoble-alpes.fr/Anglica/codjust_Scott.htm (accessed on 20 December 2018).

11. Rodzińska-Nowak, J. Napoje alkoholowe mieszkańców Barbaricum. Stud. Barbar. 2018, II, 580-588.

12. Iversen, R. The chamber grave at Ellekilde-A late Roman Iron Age princely burial and cemetery from Torslunde, East Zealand, Denmark. In Kammergräber im Barbaricum. Zu Einflüssen und Übergangsphänomenen von der Vorrömischen Eisenzeit bis in die Völkerwanderungszeit, 1st ed.; Schriften des Archäologischen Landesmuseums; Abegg-Wigg, A., Lau, N., Eds.; Wachholtz Verlag: Neumünster, Germany; Hamburg, Germany, 2014; Volume 9, pp. 133-144.

13. Schuster, J. Dobór i układ darów w inhumacyjnych grobach książęcych z pierwszej połowy I tysiąclecia po Chr. w północnej i środkowej Europie. Wiadomości Archeologiczne 2014, LXV, 5-44.

14. Isaksson, S. Food for the Gods-An analysis of organic residues from the Havor treasure. In The Havor Hoard. The Gold—the Bronzes—the Fort, 1st ed.; Nylén, E., Lund Hansen, U., Manneke, P., Eds.; Kungliga Vitterhets Historie och Antikvitets Akademien: Stockholm, Sweden, 2005; pp. 145-157.

15. Gebühr, M. Zur Definition älterkaiserzeitlicher Fürstengräber vom Lübsow-Typ. Praehistorische Zeitschrift 1974, 49, 82-128.

16. Wielowiejski, J. Życie Codzienne na Ziemiach Polskich w Okresie Wpływów Rzymskich (I-V w.), 1st ed.; Państwowy Instytut Wydawniczy: Warsaw, Poland, 1976.

17. Jellinek, E.M. Drinkers and Alcoholics in Ancient Rome. J. Stud. Alcohol. 1976, 37, 1718-1741. [CrossRef] [PubMed]

18. Ziółkowski, A. Historia Rzymu, 1st ed.; Wydawnictwo Poznańskiego Towarzystwa Przyjaciół Nauk: Poznan, Poland, 2004; pp. 126-175.

19. Encyclopaedia Britannica, s.v. Pannonia. Available online: https://www.britannica.com/place/Pannonia (accessed on 27 December 2018).

20. Gyulai, F. Historical Plant-Biodiversity in the Carpathian Basin, Archaeological and Cultural Heritage Preservation; Jerem, E., Mester, Z., Bences, R., Eds.; Archaeolingua: Budapest, Hungary, 2006; pp. 63-72.

21. Wasylikowa, K.; Cârciumaru, M.; Hartyanyi, B.; Paskevich, G.; Yanushevich, Z. East-Central Europe, Progress in Old World Palaeoethnobotany; A A Balkema Publishers: Rotterdam, The Netherlands, 1991; pp. 207-239.

22. Meschede, D. Anwendungbeispiele der Bodenkundlichen Weinbergskartierung in Hessen-Von der Datenaufbereitung zur GIS-gestützten Analyse der Weinbergslagen. Master's Thesis (Diplomarbeit), Philipps-Universität Marburg, Marburg, Germany, 2005. Available online: https://www.hlnug.de/ fileadmin/dokumente/boden/Weinbaustandortinfo/Diplomarbeit_mesch_comp.pdf (accessed on 15 December 2018).

23. Cato the Elder. De Agri Cultura; Hooper, W.D., Ash, H.B., Trans.; Loeb Classical Library: London, UK, 1934.

24. Varro. De Re Rustica; Hooper, W.D., Ash, H.B., Trans.; Loeb Classical Library: London, UK, 1934.

25. Pliny the Elder. Naturalis Historia; Taylor and Francis: London, UK, 1899.

26. Columella. De Re Rustica; Ash, H.B., Trans.; Loeb Classical Library: London, UK, 1941; Volume 1.

27. Columella. De Re Rustica; Forster, E.D., Heffner, E., Trans.; Loeb Classical Library: London, UK, 1954; Volume 2.

28. Columella. De Re Rustica; Forster, E.D., Heffner, E., Trans.; Loeb Classical Library: London, UK, 1955; Volume 3.

29. Tchernia, A. Le vin de l'Italie Romaine. Essai D'histoire Économique D'après les Amphores, 2nd ed.; Ecole française de Rome: Rome, Italy, 1986.

30. Martins, N.; Garcia, R.; Mendes, D.; Costa Freitas, A.M.; Gomes da Silva, M.; João Cabrita, M. An ancient winemaking technology: Exploring the volatile composition of amphora wines. LWT Food Sci. Technol. 2018, 96, 288-295. [CrossRef]

(C) 2019 by the authors. Licensee MDPI, Basel, Switzerland. This article is an open access article distributed under the terms and conditions of the Creative Commons Attribution (CC BY) license (http:/ / creativecommons.org/licenses/by/4.0/). 